\title{
KONSEP CULPA DALAM PERKARA PIDANA SUATU ANALISIS PERBANDINGAN PUTUSAN NOMOR 18/Pid.B/2017/PN.TOBELO
}

\section{Ernest Sengi}

(Dosen Hukum Pidana, Fakultas Ilmu Sosial dan Humaniora, Universitas Halmahera. Meraih Sarjana Hukum (SH) dari Universitas Halmahera (2012), Magister Hukum (MH) dari Universitas Kristen Satya Wacana (2015) )

Received: 20 Agustus 2019; Accepted: 03 September 2019; Published: 29 Oktober 2019

\begin{abstract}
The concept of omission or culpa from the legal aspect is very different from the concept of omission or culpa that is understood everyday. Many events include omission or culpa but the incident may not be a criminal act. Thus, law enforcement must be careful in giving meaning to a legal act related to omission. Court Decision Number 18 / Pid.B / 2017 / PN.TOb. is a decision which is the object of research in this paper, in which the author disagrees about the concept of omission or culpa which is considered by the Tobelo District Court judge in that decision, although I agrees that the defendant's actions were omission. The analysis used is legal analysis using a statute approach and case approach so that it can find out the basis of the court's consideration of choosing Pasal 359 KUHP dropped against the defendant Imsal Ilahi Baksi. In its consideration, it was found that Tobelo District Court judges interpreted omission as " not careful " or "lack of attention" so that the defendant was proven legally and convincingly committed a crime of omission. Meanwhile, in the criminal law doctrine, many concepts of omission or culpa are not always interpreted as "not careful" or "lack of attention" such as omission in the sense of onbewuste schuld. Because of the fact, in this case the defendant was careful and gave attention by notifying his actions (installing electricity), but only did not imagine the possibility of consequences.
\end{abstract}

Keywords: Criminal act, omission, court decision.

\section{PENDAHULUAN}

\section{A. Latar Belakang}

Kesalahan (schuld) dalam perkara pidana secara luas terdiri dari kesengajaan (dolus) dan keaalpaan (culpa). Kesalahan yang berbentuk kesengajaan mungkin sudah tidak menjadi hal yang asing lagi dalam pendengaran kita, sebab sebagian besar perkara-perkara pidana yang muncul ke permukaan atau yang disidangkan di pengadilan adalah kejahatan yang kesalahannya berbentuk kesengajaan; sementara kejahatan yang kesalahannya berbentuk kealpaan jarang terjadi.

Dalam hal kejahatan yang dilakukan dengan kesengajaan misalnya sengaja membunuh, sengaja mencuri dan lain sebagainya, telah terlihat bahwa kehendak untuk melakukan suatu tindak pidana dalam arti sikap batin seseorang jelas-jelas menentang suatu larangan dalam undang-undang dan dia mengetahui akibat yang akan timbul dari 


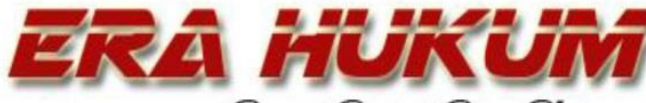 G) Iurnal Glmiah G/lmu Glukum}

Volume 17, No. 2, Oktober

tindakannya tersebut (wetens en willens). Sementara dalam hal kejahatan kealpaan, sikap batin orang yang menimbulkan keadaan yang dilarang itu bukanlah menentang larangan-larangan tersebut; dia tidak menghendaki atau menyetujui timbulnya hal yang terlarang, tetapi kesalahannya, kekeliruannya dalam batin sewaktu dia berbuat sehingga menimbulkan hal yang dilarang ialah bahwa dia kurang mengindahkan larangan itu.

\section{Perkataan kealpaan (culpa)}

dalam arti luas berarti kesalahan pada umumnya, sedang dalam arti sempit adalah bentuk kesalahan yang berupa kealpaan. Alasan mengapa culpa menjadi salah satu unsur kesalahan adalah bilamana suatu keadaan, yang sedemikian membahayakan keamanan orang atau barang, atau mendatangkan kerugian terhadap seseorang yang sedemikian besarnya dan tidak dapat diperbaiki lagi. ${ }^{1}$

Kesengajaan dan kealpaan memang sering kali dalam pandangan masyarakat merupakan dua hal yang memiliki kesamaan, hal tersebut dapat dibenarkan karena memang kesengajaan

1 Hendri Paidun, "Tinjauan Terhadap Tindak Pidana Kealpaan Yang Menyebabkan Matinya Orang Yang Dilakukan Oleh Pengemudi Kendaraan Bermotor", Jurnal Lex Crimen, Vol. II, No. 7 (November 2013): 119.
Ernest Sengi Konsep Culpa Dalam Perkara Pidana...

adalah kesalahan yang berlainan jenis dari pada kealpaan. Dasarnya adalah sama, yaitu adanya perbuatan yang dilarang dan diancam dengan pidana, adanya kemampuan bertanggung jawab, dan tidak adanya alasan pemaaf. Sama dalam konteks tersebut, namun dalam teori dan doktrin ilmu hukum kedua hal tersebut tentu berbeda.

Perbedaan antara tindak pidana kesengajaan dan kealpaan dalam praktek hukumpun sering kali sulit diklasifikasikan. Hal tersebut biasanya terlihat pada kasus-kasus yang peristiwa hukumnya bersamaan sehingga penegak hukumpun sering kali "kesulitan" dalam menerapkan norma hukum yang tepat. Berkaitan dengan hal itu, Sudarto lebih lanjut menyatakan: “dipidananya seseorang tidaklah cukup apabila orang itu telah melakukan perbuatan yang bertentangan dengan hukum atau bersifat melawan hukum. Meskipun pembuatnya memenuhi unsur delik dalam undangundang dan tidak dibenarkan, namun hal tersebut belum memenuhi syarat untuk menjatuhkan pidana. Untuk pemidanaan masih perlu adanya syarat, bahwa orang yang melakukan perbuatan itu mempunyai kesalahan atau bersalah. ${ }^{2}$

2 Sudarto dalam Septa Candra "Pembaharuan
Hukum Pidana: Konsep Pertanggungjawaban 


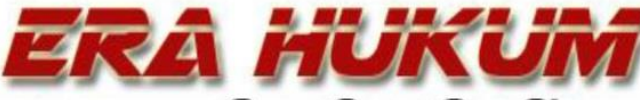

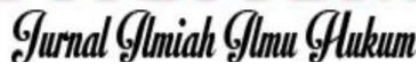

Volume 17, No. 2, Oktober

Apakah kesalahannya berbentuk kesengajaan atau kealpaan inilah yang harus diperhatikan secara baik sehingga tidak salah dalam penerapan hukum.

Salah satu kasus yang menjadi isu hukum dalam penelitian ini adalah kasus Imsal Ilahi Baksi yang diperiksa dan diputus oleh Pengadilan Negeri Tobelo karena melanggar Pasal 359 KUHP atau karena kealpaannya mengakibatkan orang mati; dimana perbuatan tersebut dilakukan Terdakwa dengan memasang colokan aliran listrik ke keramba ikan miliknya karena sebelumnya ikannya selalu dicuri orang, tetapi kemudian colokan tersebut lupa dicabut oleh Terdakwa sehingga mengakibatkan orang mati karena terkena setrum.

Kasus tersebut mengandung peristiwa yang secara sepintas memuat perbuatan yang dapat dikategorikan dilakukan dengan sengaja atau dengan kealpaan. Kebingungan tersebut juga terlihat dalam penerapan hukum oleh Jaksa Penuntut Umum dimana jaksa memasang Pasal 338 dan Pasal 359 KUHP secara bersama dalam dakwaan alternatif yang secara filosofi dakwaan ini digunakan karena adanya keraguan

Hukum Pidana Dalam Hukum Pidana Nasional yang Akan Datang", Jurnal Cita Hukum, Vol. 1, No. 1 (Juni 2013): 43.
Ernest Sengi Konsep Culpa Dalam Perkara Pidana...

tentang jenis tindak pidana yang unsurnya mirip. Seterusnya, menurut teori dakwaan alternatif adalah dakwaan yang dibentuk berdasarkan beberapa bentuk tindak pidana, namun yang dibuktikan hanyalah satu tindak pidana saja. Hal ini sejalan dengan apa yang dikatakan Yahya Harahap ${ }^{3}$, bahwa dakwaan dalam bentuk alternatif memiliki arti, antara dakwaan yang satu dengan yang lain saling "mengecualikan", atau one that substitutes for another artinya antara isi rumusan dakwan yang satu dengan yang lain saling mengecualikan dan memberi "pilihan" kepada hakim atau pengadilan untuk menentukan dakwaan mana yang tepat dipertanggungjawabkan kepada terdakwa sehubungan dengan tindak pidana yang dilakukannya.

Seterusnya atas dasar pasal tersebut Jaksa Penuntut Umum menuntut pelaku dengan pidana penjara 2 (dua) tahun. Dan berdasarkan tuntutan tersebut, hakim memilih menjatuhkan Pasal 359 KUHP sebagai pasal yang tepat atas perbuatan pelaku dan hakim menjatuhkan hukuman 1 tahun 2 bulan penjara sesuai

\footnotetext{
${ }^{3}$ M. Yahya Harahap, Pembahasan Permasalahan dan Penerapan KUHAP, Penyidikan dan Penuntutan (Jakarta: Sinar Grafika, 2008), 399.
} 


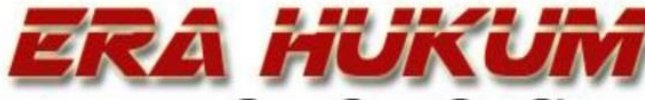 GIurnal G/miah Glımu Glukum}

Volume 17, No. 2, Oktober

putusan yang tertuang dalam Putusan No. 18/Pid.B/2017/PN.Tob.

Salah satu pertimbangan hakim sehingga memilih menjatuhkan Pasal 359 KUHP yakni bahwa berdasarkan fakta fakta yang terungkap di persidangan ternyata dapat diketahui bahwa Terdakwa memasang aliran listrik di keramba ikan karena sebelumnya ikan di kerambanya selalu dicuri sehingga terdakwa memasang kabel yang teraliri listrik dengan maksud agar jika ada yang mencoba mencuri akan tersetrum. Selanjutnya pada hari jumat tanggal 07 oktober 2016 sekitar pukul 17.30 WIT saat terdakwa memasang colokan aliran listrik yang menuju ke keramba dan kemudian melaksanakan piket sebagai Satpol PP di rumah kediaman wakil Bupati Halmahera Utara selama 12 jam sejak pukul 19.30 WIT sampai dengan pukul 07.30 WIT, dan pada keesokan harinya ketika terdakwa pulang di rumah yang seharusnya terdakwa mencabut colokan listrik, karena terdakwa ketiduran tidak di lakukan. Kemudian terdakwa bangun sekitar pukul 14.00 WIT dan langsng pergi ke kebun sehingga terdakwa tidak sempat mencabut colokan listrik tersebut, sementara pada saat ditemukan, korban Mustahidin Samad yang pada pagi
Ernest Sengi Konsep Culpa Dalam Perkara Pidana...

harinya mandi dan berenang disekitar kerambah yang dikelola oleh terdakernywa ditemukan dalam keadaan tidak bernyawa lagi ( hal. 19 Putusan No.18/Pid.B/2017/PN.Tob ).

Pertimbangan pengadilan tersebut menunjukan bahwa konsep kealpaan dalam Pasal 359 KUHP yang dipahami hakim adalah bentuk kelalaian karena terdakwa "lupa" dalam mencabut colokan listrik yang dipasangnya sehingga mengakibatkan matinya orang karena terkena setrum. Konsep kealpaan oleh hakim tersebut akan dianalisis secara hukum oleh penulis karena dalam pemidanaan kealpaan tidak dipahami sesederhana itu atau dengan kata lain cukup dengan terpenuhinya unsur Pasal 359 KUHP lalu menjadi dasar dipidannya seorang terdakwa.

\section{B. Rumusan Masalah}

Berdasarkan uraian yang telah dideskripsikan pada bagian latar belakang, permasalahan yang diangkat dalam tulisan ini adalah apakah konsep kealpaan yang dipertimbangkan Hakim Pengadilan Negeri Tobelo dalam Putusan Nomor 18/Pid.B/2017/PN.Tob. sudah tepat?

\section{Metode Penelitian}

Tulisan ini merupakan penelitian hukum yang jenisnya normatif. Penelitian 


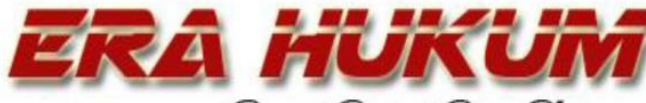 \\ Gurnal GImiah Glım Glukum}

Volume 17, No. 2, Oktober

hukum yang jenisnya normatif dilakukan dengan cara mengkaji data sekunder yang diinventarisir dalam bahan-bahan pustaka. ${ }^{4}$ Biasanya penelitian jenis ini terdiri dari bahan-bahan hukum yakni bahan hukum primer berupa peraturan perundang-undangan, putusan-putusan Pengadilan; bahan hukum sekunder berupa literatur ilmu hukum, karya-karya ilmiah hukum; dan bahan hukum tersier dapat berupa kamus hukum dan kamus bahasa Indonesia.

Setelah semua bahan hukum diperoleh dengan lengkap, seterusnya diklasifikasi bahan hukum mana yang sesuai dengan permasalahan yang dikaji kemudian dilakukan analisis hukum dengan menggunakan pendekatan hukum yang dalam penelitian ini digunakan pendekatan undang-undang (statute aprroach) dan pendekatan kasus (case aprroach). ${ }^{5}$ Kedua pendekatan ini tepat sesuai dengan objek kajian yang hendak diteliti yakni bagaimana ratio decidendi atau dasar pertimbangan pengadilan/hakim dalam menjatuhkan putusan dengan menerapkan Pasal 359 KUHP. Setelah analisis selesai dilakukan

\footnotetext{
${ }^{4}$ Soerjono Soekanto dan Sri Mamudji, Penelitian Hukum Normatif, Suatu Tinjauan Singkat (Jakarta: Raja Grafindo Persada, 2012), 12.

5 Peter Mahmud Marzuki, Penelitian Hukum, edisi revisi (Jakarta: Kencana Prenada Media Grup, 2013), 136 dan 158.
}

Ernest Sengi Konsep Culpa Dalam Perkara Pidana...

maka akan diberikan preskripsi hukum dan kesimpulan apakah konsep kealpaan yang terkandung dalam Pasal 359 KUHP sudah tepat diterapkan hakim dalam putusan Nomor 18/Pid.B/2017/PN.Tob.

\section{PEMBAHASAN}

\section{A. Kealpaan dalam Doktrin Hukum Pidana}

Seperti yang telah dijelaskan pada bagian sebelumnya bahwa kesalahan dalam arti luas meliputi kesengajaan (dolus) dan kealpaan (culpa); hal tersebut mengandung arti bahwa di samping kesengajaan, orang juga dapat dipidana bila melakukan kejahatan yang kesalahannya berbentuk kealpaan.

Salah satu pasal yang terdapat dalam KUHP yang merupakan kejahatan kealpaan yakni Pasal 359 KUHP $^{6}$, dimana dapat dipidananya orang yang menyebabkan matinya orang lain karena kesalahannya atau kealpaannya. Menurut Lamintang, terkait ketentuan Pasal 359 KUHP tersebut diketahui bahwa bagi meninggalnya seseorang itu undangundang telah mensyaratkan adanya unsur schuld atau culpa pada diri pelaku. ${ }^{7}$

\footnotetext{
${ }^{6}$ Gerry M. Rizki, KUHP dan KUHAP (Jakarta: Permata Press, 2008), 120.

${ }^{7}$ P.A.F. Lamintang dan Theo Lamintang, DelikDelik Khusus: Kejahatan Terhadap Nyawa, Tubuh dan Kesehatan (Jakarta: Sinar Grafika, 2010), 211.
} 


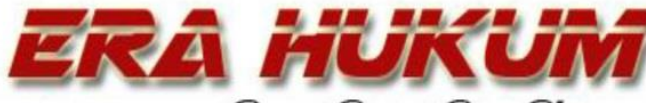 G) Iurnal Glmiah G/lmu Glukum}

Volume 17, No. 2, Oktober

Mengenai kealpaan ini, pembentuk W.v.S (Smidt 1 - 825) memberikan penjelasan berbunyi:

"Pada umumnya bagi kejahatankejahatan wet mengharuskan bahwa kehendak terdakwa ditujukan pada perbuatan yang dilarang dan diancam dengan pidana. Kecuali itu keadaan yang dilarang itu mungkin sebagian besar berbahayannya terhadap keamanan umum mengenai orang atau barang dan jika terjadi menimbulkan banyak kerugian, sehingga wet harus bertindak pula terhadap mereka yang tidak berhatihati, yang teledor. Di sini sikap batin orang yang menimbulkan keadaan yang dilarang itu bukanlah menentang larangan-larangan tersebut; dia tidak menghendaki atau menyetujui timbulnya hal yang terlarang, tetapi kesalahannya, kekeliruannya dalam batin sewaktu ia berbuat sehingga menimbulkan hal yang dilarang dalam arti ia kurang mengindahkan larangan itu".

Sejalan dengan hal tersebut, lebih lanjut disebutkan pada Konsep Rancangan KUHP, yakni "Tindak pidana dilakukan dengan kealpaan, jika pembuatnya telah tidak berhati-hati sebagaimana seharusnya, dan atau tidak menduga terlebih dahulu tentang akan terjadinya akibat yang terlarang, atau
Ernest Sengi Konsep Culpa Dalam Perkara Pidana...

walaupun menduga bahwa akibat yang terlarang itu mungkin dapat ditimbulkan oleh perbuatannya, tetapi ia berkeyakinan dapat menghindarkan terjadinya akibat tersebut, sedangkan kenyataannya adalah sebaliknya. ${ }^{8}$

Berdasarkan pada keterangan KUHP tersebut kejahatan kealpaan dapat dipahami terjadi bukanlah semata-mata seorang menentang larangan tersebut dengan justru melakukan yang dilarang itu. Tetapi dia tidak begitu mengindahkan larangan, hal ini nyata dari perbuatannya. Hal tersebutlah sehingga oleh Moeljatno ${ }^{9}$ disebut dengan gecompliceerd.

Pada prinspinya seseorang dapat dikatakan mempunyai culpa di dalam melakukan perbuatannya apabila orang tersebut telah melakukan perbuatannya tanpa disertai "de nodige en mogelijke voorzichtigheid en oplettendheid" atau tanpa disertai kehati-hatian dan perhatian seperlunya yang mungkin ia dapat berikan. ${ }^{10}$ Oleh karena itu maka menurut Simons, culpa itu pada dasarnya mempunyai dua unsur masing-masing yakni "het gemis aan voorzichtigheid"

\footnotetext{
${ }^{8}$ I Made Minggu Widyantara, "Kesengajaan dan Kealpaan (Suatu Tinjauan dari Sudut Perbandingan Hukum Pidana Indonesia dengan Hukum Pidana Asing)", Jurnal Kertha Wicaksana, Volume 21, No. 1 (Januari 2017): 3. ${ }^{9}$ Moeljatno, Asas-Asas Hukum Pidana (Jakarta: Rineka Cipta, 2008), 217.

${ }^{10}$ Simons, Leerboek I,. 267.
} 


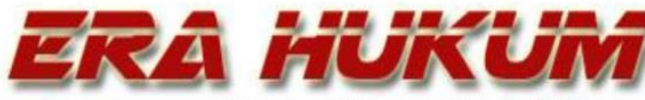 \\ GIurnal G/miah Glımu Glukum}

Volume 17, No. 2, Oktober

dan "het gemis van de voorzienbaarheid" atau "tidak adanya kehati-hatian" dan "kurangnya perhatian terhadap akibat yang dapat timbul". Sejalan dengan hal tersebut, menurut Van Hamel, ${ }^{11}$ sebagaimana dikutip Moejatno bahwa kealpaan itu mengandung dua syarat, yaitu: pertama, tidak mengadakan praduga-duga sebagaimana diharuskan oleh hukum. Kedua, tidak mengadakan penghati-hati sebagaimana diharuskan oleh hukum.

Selain apa yang telah disebutkan di atas, ada pula yang disebut dengan culpa atau kelalaian / kealpaan yang dalam doktrin hukum pidana dikenal sebagai kealpaan yang tidak disadari atau onbewuste schuld dan kealpaan yang disadari atau bewute schild. Faktor terpenting dalam unsur ini adalah pelaku dapat menduga terjadinya akibat dari perbuatannya itu, atau pelaku kurang berhati-hati. Wilayah culpa ini terletak diantara sengaja dan kebetulan. Oleh sebab itu, untuk mempertanggujawabkan perbuatan, hubungan batin terdakwa dengan akibat yang timbul harus dibuktikan adanya hubungan kausal sehingga dapat ditentukan kesalahannya.

Mengenai kesalahan, Sudarto mengatakan pula pengertian kesalahan
Ernest Sengi Konsep Culpa Dalam Perkara Pidana...

psikologis dan pengertian kesalahan yang normatif. Pengertian kesalahan yang psikologis bahwa kesalahan hanya dipandang sebagai hukum psikologis (batin) antara sipembuat dan perbuatannya. Pada kesengajaan hubungan batin itu berupa menghendaki perbuatan (beserta akibatnya) dan pada kealpaan tidak ada kehendak demikian. Jadi, disini hanya digambarkan keadaan batin sipembuat, sedangkan yang menjadi ukurannya adalah sikap batin yang berupa kehendak terhadap perbuatan atau akibat perbuatan. Adapun pengertian kesalahan yang normatif, menentukan kesalahan seseorang tidak hanya berdasarkan sikap batin atau hubungan batin antara pembuat dan perbuatannya. Penilaian normatif artinya penilaian dari luar mengenai hubungan antara pembuat dan perbuatannya. Penilaian dari luar ini merupakan pencelaan dengan memakai ukuran yang terdapat dalam masyarakat ialah apa yang seharusnya diperbuat oleh sipembuat. Didalam pengertian ini, sikap batin sipembuat berupa kesengajaan dan kealpaan tetap diperhatikan, namun hanya merupakan unsur dari kesalahan aatau unsur lain yaitu penilaian mengenai keadaan jiwa sipembuat, ialah

\footnotetext{
${ }^{11}$ Moeljatno, Ibid.
} 


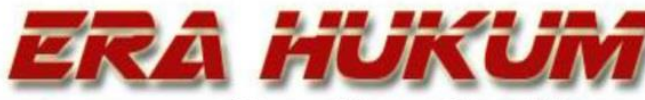 \\ GIurnal G/miah Glımu Glukum}

Volume 17, No. 2, Oktober

kemampuan bertanggungjawab dan tidak hanya penghapusan kesalahan. ${ }^{12}$

Berdasarkan beberapa penjelasan tersebut dapat disimpulkan bahwa secara umum kealpaan mengandung dua syarat yakni pertama, tidak mengadakan praduga-duga yang perlu menurut hukum, dan kedua, tidak mengadakan penghatihati sebagaimana diharuskan oleh hukum.

Mengenai syarat pertama yakni "tidak mengadakan praduga-duga yang perlu menurut hukum", ada dua kemungkinan yaitu pertama, terdakwa berpikir bahwa akibat tidak akan terjadi karena perbuatannya, padahal pandangan itu kemudian ternyata tidak benar. Kedua, terdakwa sama sekali tidak mempunyai pikiran bahwa akibat yang dilarang mungkin timbul karena perbuatannya. Dalam hal yang pertama kekeliruan terletak pada salah pikir atau pandang, yang seharusnya disingkiri. Dalam hal kedua terletak pada tidak mempunyai pikiran sama sekali bahwa akibat mungkin akan timbul, hal mana adalah sikap yang berbahaya.

Dengan syarat pertama tersebut, maka diletakan hubungan antara batin

\footnotetext{
12 Hariati Kalia, "Pembuktian Tindak Pidana dengan Terang-Terangan dan Tenaga Bersama Menggunakan Kekerasan Terhadap Orang yang Mengakibatkan Luka-Luka", Jurnal Ilmu Hukum Legal Opinion Edisi 4, Volume 1, (2013): 6.
}

Ernest Sengi Konsep Culpa Dalam Perkara Pidana...

terdakwa dengan akibat yang timbul karena perbuatannya. Hubungan ini senyatanya tidak perlu ada dalam psyche terdakwa, karena kita menganut ajaran kesalahan yang normatif, tidak lagi secara psikologis, maka yang menentukan ialah apakah hubungan itu dipernilai ada atau tidak ada. Hubungan batin ini diperlukan untuk dapat mempertanggungjawabkan terhadap timbulnya akibat yang dilarang.

Selain dari adanya hubungan batin ini tentu saja lebih dahulu harus ada hubungan lahir antara perbuatan terdakwa dan akibat yang dilarang. Di situ harus ada hubungan kausal. Kalau ini tidak ada, tidak akan mungkin dipertanggungjawabkan secara hukum. Seterusnya, dalam menilai ada tidaknya hubungan antara batin terdakwa dengan akibat yang terlarang tidaklah diambil pendirian seseorang pada umumnya, tetapi diperhatikan keadaan terdakwa itu persoonlijk. Hal ini mengandung arti, apakah terdakwa seharusnya menduga akan kemungkinan timbulnya akibat untuk ini diperhitungkan pula pekerjaannya, keahliannya, dan sebagainya.

Adakah syarat batin harus dibutuhkan dan karena itu harus dibuktikan oleh jaksa, hal ini adalah 


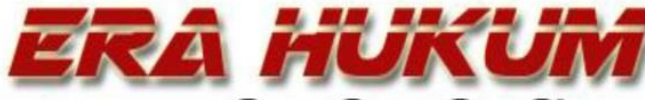 \\ Glurnal GImiah G/lmu Glukum}

Volume 17, No. 2, Oktober

sukar sekali untuk membuktikan, bahwa ada menduga-duga yang diperlukan oleh hukum itu. Karena itu HR menganggap tidak perlu. Dalam arest 1911 dikatakan: "hal bahwa akibat yang dilarang itu dapat diduga-duga sebelumnya tidak perlu disebutkan tersendiri dalam surat tuduhan". Syarat itu sudah tersimpul dalam tuduhan "karena kealpaan”. Tentu saja terdakwa selalu boleh membuktikan bahwa dia tidak mungkin untuk menduga-duga akan timbulnya akibat, sekalipun menggunakan kewaspadaan yang ada padanya.

Mengenai syarat kedua yakni "tidak mengadakan penghati-hati sebagaimana diharuskan oleh hukum", mengenai syarat ini van Hamel ${ }^{13}$ menerangkan "ini antara lain ialah tidak mengadakan penelitian, kebijaksanaan, kemahiran atau usaha pencegah yang ternyata dalam keadaan-keadaan yang tertentu atau dalam caranya melakukan perbuatan". Jadi yang menjadi objek peninjauan dan penilaian bukan batin terdakwa tetapi apa yang dilakukan atau tingkah laku terdakwa sendiri. Tetapi, yang menjadi pertanyaan ialah apakah tingkah laku terdakwa dalam keadaankeadaan yang tertentu itu ataupun dengan cara yang telah dilakukan itu, menurut

\footnotetext{
${ }^{13}$ Moeljatno, Op.,Cit.,hal. 220.
}

Konsep Culpa Dalam Perkara Pidana...

ukuran-ukuran yang berlaku dalam pergaulan masyarakat sudah dipandang betul? Dalam arti apakah sudah mencocoki suatu standar yang tertentu mengenai penghati-hati yang lahir. Dan ini tidak diadakan untuk orang pada umumnya, tetapi untuk orang dalam keadaan-keadaan khusus seperti terdakwa. Artinya: diperhitungkan pula pekerjaannya, keahliannya, dan lainnya sama halnya dengan syarat yang pertama sebelumnya.

Syarat yang kedua inilah menurut praktik yang penting guna menentukan adanya kealpaan. Inilah yang harus dituduhkan dan harus dibuktikan oleh jaksa. Sesungguhnya kalau syarat ini sudah ada maka pada umumnya syarat yang pertama juga sudah ada. Barang siapa yang dalam melakukan suatu perbuatan tidak mengadakan penghatihati yang seperlunya, maka dia juga tidak menduga-duga akan terjadinya akibat yang tertentu itu karena kelakukannya. Pemahaman yang boleh dikatakan objektif ini, yaitu yang menitikberatkan makna kealpaan pada sifatnya perbuatan terdakwa.

Di dalam sistem Hukum Pidana kita masih mencampurkan (menyatakan) pengertian tindak pidana dengan pertanggungjawaban pidana, artinya 


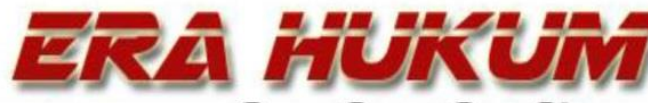 G/urnal G/miah Glmu Glukum}

Volume 17, No. 2, Oktober

masalah pertanggung jawaban pidana merupakan bagian dari rumusan tindak pidana (delik). Ini dapat dilihat pada setiap rumusan tindak pidana (delik) selalu mencantumkan unsur "sengaja" atau unsur "kealpaan". Konsekuensi ini sebagai akibat dari diterimanya konsep Strafbaarfeit Hukum Pidana Belanda ke dalam pengertian tindak pidana dalam Hukum Pidana Indonesia.

Sebagaimana telah dikatakan bahwa masalah pertanggungjawaban pidana adalah tentang kesalahan yang mempunyai bentuk berupa "kesengajaan" dan "kealpaan" dan unsur ini merupakan syarat mutlak yang harus ada bila hendak menjatuhkan pidana. Namun di dalam KUHP Muangthai menganut prinsip yang berbeda dengan KUHP Indonesia khususnya tentang kealpaan.

Pasal 59 KUHP Muangthai antara lain merumuskan sebagai berikut:

"Seseorang hanya akan
dipertanggung- jawabkan apabila
ia melakukan suatu perbuatan
dengan sengaja, kecuali: undang-
undang menentukan bahwa ia
harus dipertanggung- jawabkan
apabila ia melakukan suatu
perbuatan dengan kealpaan, atau
undang- undang secara jelas
menetapkan bahwa ia harus
bertanggung jawab walaupun ia
melakukan perbuatan tidak
dengan sengaja". Di dalam bahasa
aslinya pasal 59 KUHP

Ernest Sengi Konsep Culpa Dalam Perkara Pidana...

Muangthai ini menyebutkan: " $a$ person shall be criminally liable only when he commits an act intentionally, except in the case where the law provides that he must be liable when he commits an act by negligence, or except in the case where the clearly provides that he must be liable even though he commits an act unintentionally".

Jadi menurut ketentuan Pasal 59 KUHP Muangthai tersebut menyatakan: kealpaan baru dapat dipidana bila undang-undang secara tegas menyebutkan sebagai perbuatan yang dapat dipidana. Ketentuan serupa dianut pula oleh KUHP Jepang maupun KUHP Swiss, dimana di dalam Pasal 38 KUHP Jepang dan Pasal 18 KUHP Swiss menyatakan: suatu perbuatan yang dilakukan tanpa sengaja tidak dapat dipidana, kecuali ditentukan khusus oleh Undang-Undang. Ketentuan ini sangat modern, karena oleh Andi Hamzah menunjukkan perbedaan antara "Criminal $A c t$ " (tindak pidana) dengan "Criminal Liability" (pertanggung jawaban pidana). ${ }^{14}$

Dari beberapa KUHP negara asing tersebut di atas pada dasarnya menganut prinsip hanya orang yang melakukan perbuatan dengan sengaja sajalah yang dapat dinyatakan bersalah

\footnotetext{
${ }^{14}$ I Made Minggu Widyantara, Op.,Cit. hal. 2.
} 


\section{ERA HUKün

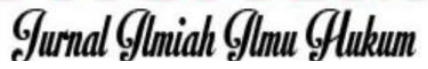

Volume 17, No. 2, Oktober

dan dijatuhkan pidana. Sedang dipidannya orang yang melakukan perbuatan karena kealpaan hanya merupakan suatu pengecualian (eksepsional), yaitu apabila ditentukan secara khusus oleh undang-undang.

\section{B. Intisari Putusan Nomor 18/Pid.B/2017/PN.Tob.}

\section{Kasus Posisi}

Bahwa Imsal Ilahi Baksi yang adalah seorang honorer satuan Polisi Pamong Praja, asal dari desa Igobula Kecamatan Galela Selatan. Imsal pada bulan maret 2016 bersama warga desa Igobula membentuk sebuah kelompok usaha tani di bidang perikanan dan diberi nama Bunga Maloha. Keramaba tersebut berisi ikan mujair dan nila namun berjalannya waktu kenyataan yang mengelola keramba hanya Imsal Ilahi Baksi sendiri. Dan rencananya pada bulan juni 2016 akan diadakan panen namun pada tanggal 2 Juni 2016 istrinya melahirkan di rumah sakit umum Hasan Boesoiri Ternate sehingga Imsal berada di Ternate, dan pada tanggal 8 Juni Imsal sendiri harus kembali ke Igobula. Lalu Imsal langsung menuju ke keramba ikan untuk melihat ikan yang siap dipanen.

Ternyata ikan yang siap dipanen sudah habis dicuri orang, terdapat tanda-
Ernest Sengi Konsep Culpa Dalam Perkara Pidana...

tanda pencurian berupa jaring sudah dinaikan diatas papan kerambah. Setelah itu Imsal pindahkan keramba ke tempat yang lebih jauh dengan jarak kurang lebih $100 \mathrm{~m}$ (seratus meter), dan merawat ikan yang sisa serta memisahkan yang ukuran kecil, sedang, dan ukuran besar, tetapi terus-menerus terjadi pencurian sebanyak kurang lebih empat kali, yang mengakibatkan secara keseluruhan sebanyak 4000 (empat ribu) ekor ikan mujair dan ikan nila, dan secara keseluruhan Imsal mengalami kerugian kurang lebih sebesar Rp 4.000.000 (empat juta rupiah), namun tidak diketahui siapa pelakunya, sehingga Imsal merasa sangat sakit hati dan kecewa, dan akhirnya pada sekitar akhir bulan Agustus 2016 Imsal memasang aliran listrik di keramba ikan milik kelompok tani “ bunga maloha”.

Bahan yang Imsal gunakan adalah colokan, terminal, kabel yang dijual di toko yakni kabel merah bening kurang lebih sepanjang 80 ( delapan puluh ) meter, dan 1 ( satu ) urat kabel PLN ( almunium ) yang Imsal dapat dari temannya kurang lebih sepanjang 16 (enam belas) meter, alurnya adalah colokan dan terminal terletak bagian dapur rumah Imsal, dari dapur hingga ke keramba ikan menggunakan kabel toko 
Volume 17, No. 2, Oktober

( merah-bening ) lalu Imsal sambungkan dengan seutas kabel almunium telanjang untuk mengelilingi keramba pada semua sisi, kabel telanjang yang ada di keramba berada dibagian atas pada sisi luar papan dengan maksud agar muda dilihat, akan tetapi strum yang Imsal gunakan di colokan dan terminal hanyalah satu kutub yaitu kutub positif saja yang mana menimbulkan efek strum kejut. Lalu akhirnya mengakibatkan korban Mustahidin Samad meninggal dunia terkena setrum yang tidak lain berada dalam keramba ikan milik Imsal, yang saat itu korban sedang berenang di Telaga.

\section{Dakwaan dan Tuntutan Jaksa \\ Penuntut Umum}

Berdasarkan kasus posisi yang telah diuraikan tersebut, Jaksa Penuntut Umum dalam surat dakwaannya di persidangan menuntut terdakwa Imsal Ilahi Baksi dengan dakwaan alternatif yakni Pertama, Terdakwa melanggar Pasal 338 KUHP karena diduga dengan sengaja merampas nyawa orang lain, atau kedua, Terdakwa melanggar Pasal 359 KUHP karena diduga karena kealpaannya mengakibatkan orang lain meninggal.

Seterusnya Jaksa Penuntut Umum memohon pengadilan untuk memeriksa dan menjatuhkan putusan dengan tuntutan:

a. Menyatakan terdakwa Imsal Ilahi Baksi alias Imsal bersalah melakukan tindak pidana " Karena kelalaiannya atau kealpaannya mengakibatkan matinya orang lain yaitu korban an. Mustahidin Samad alias Tahidin " sebagaimana diatur dan diancam pidana dalam Pasal 359 KUHP

b. Menjatuhkan pidana terhadap terdakwa berupa pidana penjara selama 2 (dua) tahun dengan dikurangi selama terdakwa berada dalam tahanan

c. Menetapkan agar terdakwa tetap berada dalam tahanan

d. Menetapkan barang bukti berupa :

- 7070 ( tujuh ribu tujuh puluh ) cm, kabel warna merah dan putih bening

- 2500 ( dua ribu lima ratus ) cm kawat

- 1 ( satu ) buah mata cok warna putih

Dirampas dan dimusnakan 
Volume 17, No. 2, Oktober

5. Menetapkan agar terdakwa membayar biaya perkara sebesar Rp. 3.000,

( tiga ribu rupiah ).

\section{Pertimbangan Hakim dan Putusan}

Sesuai dengan isi dakwaan serta tuntutan Jaksa Penuntut Umum dan faktafakta yang terungkap di persidangan, majelis hakim Pengadilan Negeri Tobelo hendak menjatuhkan hukuman kepada terdakwa Imsal Ilahi Baksi dengan memberi pertimbangan - pertimbangan sebagaimana diuraikan di bawah ini:

Berdasarkan fakta yang terungkap di persidangan bahwa terdakwa Imsal Ilahi Baksi adalah benar seorang Satuan Polisi Pamong Praja honorer, berasal dari desa Igobula Kecamatan Galela Selatan, untuk memperkuat hal tersebut terdakwa di depan persidangan telah mengakui dan membenarkan seluruh identitasnya sebagaimana dalam surat dakwaan Jaksa Penuntut Umum.

Menimbang, bahwa setelah pembacaan tuntutan Penuntut Umum, terdakwa maupun Penasihat Hukumnya telah mengajukan pembelaan secara lisan yang pokoknya menyatakan telah menyesali perbuatannya dan mohon hukuman yang seringan - ringannya.
Menimbang, bahwa kemudian pembelaan terdakwa tersebut, Penuntut Umum menyatakan secara lisan pada Repliknya tetap pada tuntutannya, demikian pula selanjutnya terdakwa maupun Penasihat Hukumnya menyatakan dalam dupliknya tetap pada pembelaannya.

Menimbang, bahwa dari keadaan - keadaan yang terjadi di persidangan, berdasarkan keterangan saksi - saksi, keterangan terdakwa dan alat bukti yang lain, kemudian Majelis Hakim akan mempertimbangkan, apakah terdakwa terbukti melakukan perbuatan pidana sebagaimana yang didakwakan oleh Penuntut Umum.

Menimbang, bahwa oleh Penuntut Umum terdakwa didakwa dengan dakwaan:

- Kesatu melanggar Pasal 338 KUHP, atau

- Kedua melanggar Pasal 359 KUHP

Menimbang, bahwa oleh karena dakwaan yang disusun Alternatif, maka Majelis Hakim akan terlebih dahulu akan membuktikan dakwaan yang berdasarkan fakta-fakta yang labih mendekati unsur unsur yang terangkum yaitu melanggar Pasal 359 KUHP yang unsur pokoknya sebagai berikut: 
Volume 17, No. 2, Oktober

\section{Unsur Karena Kelalaianya atau} Kealpaannya

Menimbang, bahwa yang dimaksud dengan kelalaian atau kealpaan adalah kurang hati - hati, atau kurang perhatian. Menimbang, bahwa sebagaimana keterangan saksi - saksi yang saling bersesuaian satu dengan yang lain telah di peroleh fakta-fakta. Menimbang, bahwa berdasarkan fakta fakta tersebut ternyata dapat diketahui bahwa terdakwa memasang aliran listrik di keramba ikan tersebut karena sebelumnya ikan di kerambanya dicuri sehingga terdakwa memasang kabel yang teraliri listrik dengan maksud agar jika ada yang mencoba mencuri akan tersetrum.

Selanjutnya pada hari jumat tanggal 07 oktober 2016 sekitar pukul 17.30 WIT saat terdakwa memasang colokan aliran listrik yang menuju ke keramba dan kemudian melaksanakan piket sebagai Sapol PP di rumah kediaman wakil Bupati Halmahera Utara selama 12 jam sejak pukul 19.30 WIT sampai dengan pukul 07.30 WIT, dan pada keesokan harinya ketika terdakwa pulang di rumah yang seharusnya terdakwa mencabut colokan listrik, karena terdakwa ketiduran tidak di lakukan. Kemudian terdakwa bangun sekitar pukul 14.00 WIT dan langsng pergi ke kebun sehingga terdakwa tidak sempat mencabut colokan listrik tersebut.

Menimbang, bahwa memperhatikan keadaan tersebut maka menurut Majelis Hakim unsur karena kelalaiannya atau kealpaannya telah terpenuhi dan terbukti.

\section{Unsur yang Mengakibatkan Orang}

\section{Lain Mati}

Menimbang, bahwa sebagaimana fakta - fakta sebagaimana tersebut diatas dan sesuai dengan hasil Visum Et Repertum tertanggal 23 November 2016 yang dibuat dan ditanda tangani oleh dr. William, dokter pemeriksa pada RSUD Tobelo. Berdasarkan kesimpulan visum et repertum bahwa terdapat luka akibat trauma listrik yang mengakibatkan korban meninggal dunia, sehingga dengan demikian maka unsur mengakibatkan orang lain meninggal telah terpenuhi.

Menimbang, bahwa dari pertimbangan - pertimbangan tersebut diatas, yang didasarkan pada alat - alat bukti yang sah maka timbul keyakinan Majelis Hakim bahwa terdakwa telah terbukti secara sah melakukan tindak pidana sebagaimana dakwaan Penuntut Umum. 
Ernest Sengi

Menimbang, bahwa dengan terbuktinya terdakwa melakukan tindak pidana dalam dakwaan tersebut, dan selama dalam persidangan pada diri terdakwa tidak diketemukan adanya alasan penghapus pemidanaan baik berupa alasan pemaaf maupun alasan pembenar, maka terdakwa haruslah dinyatakan bersalah dan patut dijatuhi pidana berdasrkan dakwaan tersebut.

Oleh sebab itu berdasarkan pertimbangan tersebut, maka Pengadilan Negeri Tobelo melalui Majelis hakim mengadili sebagai berikut :

1. Menyatakan terdakwa Imsal Ilahi Baksi alias Sal, telah terbukti secara sah dan menyakinkan bersalah melakukan tindak pidana "karena kelalaiannya mengakibatkan orang lain meninggal dunia"

2. Menjatuhkan Pidana terhadap terdakwa oleh karena itu dengan pidana penjara selama 1 (satu) tahun dan dua (dua) bulan

3. Menetapkan lamanya terdakwa dalam tahanan akan dikurangkan seluruhnya dari pidana yang dijatuhkan
4. Menetapkan terdakwa tetap berada dalam tahanan

5. Menyatakan barang bukti berupa :

- 7070 (tujuh ribu tujuh puluh) cm kabel warna merah dan putih bening

- 2500 (dua ribu lima ratus) cm kawat

- 1 (satu) buah mata cok warna putih

Dirampas dan dimusnahkan

6. Membebankan kepada terdakwa untuk membayar biaya perkara sebesar Rp. 3000, (tiga ribu rupiah).

\section{Analisis Hukum}

Karena majelis hakim memilih Pasal 359 KUHP untuk dijatuhkan terhadap terdakwa, maka berikut Penulis akan menguraikan analisis hukum atas Pasal 359 tersebut yang bunyinya sebagai berikut :

"Barangsiapa karena kesalahannya (kealpaannya) mengakibatkan orang lain mati, diancam dengan pidana penjara paling lama lima tahun 
Ernest Sengi

Glurnal Glmiah Glmu Glukum

Volume 17, No. 2, Oktober

atau pidana kurungan

paling lama satu tahun ".

Dari uraian Pasal 359 KUHP tersebut maka yang menjadi bagian inti delik dari pasal tersebut adalah:

\section{Unsur Barang Siapa}

Unsur barangsiapa menunjukan pada subjek hukum "manusia" (terdakwa). Subjek hukum merupakan pendukung hak dan kewajiban dan yang dapat dikategori sebagai subjek hukum yaitu manusia dan badan hukum. Subjek hukum dalam hal ini selaku pendukung hak dan kewajiban dimana subjek hukum yang dinilai mampu secara fisik maupun mental dapat mempertanggungjawabkan apa yang dilakukan ketika dia melanggar hukum yang berlaku. Subjek hukum yang dimaksud dalam perkara ini adalah terdakwa Imsal Ilahi Baksi. Dimana terdakwa setelah diperiksa dan diteliti dalam perkara ini dianggap cakap dalam hukum. Artinya menurut hukum pidana terdakwa mampu secara fisik maupun mental (sehat jasmani dan rohani) untuk mempertanggungjawabkan perbuatan pidana yang telah dilakukannya. Oleh sebab itu menurut Penulis unsur barangsiapa tepat dikenakan kepada terdakwa Imsal Ilahi Baksi.

\section{Unsur Karena Kesalahannya}

\section{(Kealpaannya)}

Dalam hukum pidana dikenal ada dua kesalahan yakni kesengajaan (opset/dolus) dan kealpaan (culpa). Menurut Lamintang ${ }^{15}$, Kealpaan (culpa) oleh para penulis Belanda disitilahkan salah satu bagian dari Schuld. Menurut mereka bahwa pengertian Schuld itu tidak selalu sama dengan pengertian Culpa. Oleh karena itu Schuld dalam hubungannya dengan ajaran mengenai Schuld atau apa yang juga disebut Schuldleer itu biasanya juga dibicarakan pada waktu orang membicarakan masalah Opset dan Schuld dalam arti dolus dan culpa, sedang yang ingin Lamintang maksudkan yaitu semata-mata mengenai Culpa.

Menurut Lamintang bahwa pembentukan Kitab Undang - Undang Hukum Pidana telah mempergunakan perkataan "Schuld" untuk menunjukan unsur "Culpa" di dalam suatu rumusan delik. Akan tetapi dalam maksud yang sama pembentuk undang - undang juga telah mempergunakan perkataanperkataan lain, misalnya perkataan "ernestige redden habben om te

15 P.A.F. Lamintang, Dasar-Dasar Hukum Pidana Indonesia (Bandung: Citra Aditya Bakti, 1997), 334 - 335. 


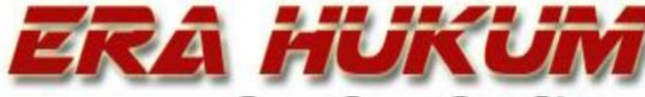

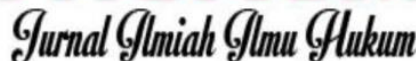

Volume 17, No. 2, Oktober

vermoeden" yang artinya " mempunyai alasan yang cukup kuat untuk menduga " dan perkataan "redelijker wijze moeten vermoeden" yang artinya "secara pantas harus menduga" bahwa suatu keadaan itu memang ada. Di dalam rumusan-rumusan delik selebihnya di mana terdapat unsur “Culpa”, biasanya pembentuk undang undang mempergunakan perkataan " aan wiens schuld te wijten is" yang berarti "yang dapat dipersalahkan karena kesalahannya" yakni seperti misalnya yang sering dijumpai dalam rumusanrumusan delik menurut Pasal - Pasal 114, 359, 360, 409, dan 426 ayat 2 KUHP. Selanjutnya dalam Memorie van Toelichting kita dapat menjumpai sekadar penjelasannya mengenai pengertian Culpa yang mengatakan bahwa : "Schuld is de zuivere tegenstelling van opzet aan de eene kant, van toeval aan de andere zijde" yang artinya : "Schuld (baca : culpa) itu merupakan kebalikan secara murni dari Opzet disatu pihak dan kebalikan dari kebetulan dilain pihak." Mengenai hal ini van Bemmelen 16 mengatakan " Ernestige redden habben om te vermoeden dan redelijkkerwijze moeten vermoeden" itu belum merupakan suatu waten. Ia merupakan suatu rumusan tentang Schuld dalam arti kekurang hati -

${ }^{16}$ Ibid., hal. 336.
Ernest Sengi Konsep Culpa Dalam Perkara Pidana...

hatian atau onbewuste schuld. Dimana si pelaku tidak mengetahui bahwa suatu keadaan itu ada, dan ketidaktahuannya itu disebabkan karena ia kurang hati-hati atau karena ia acuh tak acuh.

Dalam perkara ini, terdakwa dijatuhi pidana karena terbukti melanggar unsur Pasal 359 KUHP yakni karena kealpaanya mengakibatkan orang mati, dimana perbuatan terdakwa yang menurut majelis hakim "karena kurang hati - hati atau kurang perhatian akan akibat yang dapat timbul" sehingga tidak mencabut colokan listrik yang telah dipasang sebelumnya sehingga menyebabkan orang mati karena terkena setrum. Pertimbangan hakim tersebut kurang disepakati Penulis karena tidak semua culpa itu dapat dikembalikan kepada "tidak adanya kehati - hatian" dan kepada “ kurangnya perhatian terhadap akibat yang dapat timbul" ataupun kepada "tidak adanya perhatian ke depan yang diperlukan”. Seperti yang dipertimbangkan oleh hakim terhadap kasus Imsal Ilahi Baksi dalam putusan halamn 17.

Sebagai contoh misalnya seorang penjaga pintu jalan kereta api yang justru karena kehati-hatiannya dan karena kesadarannya akan kemungkinan timbulnya satu kecelakaan apabila ia 


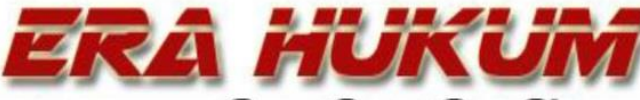 \\ GIurnal G/miah G/mu Glukum}

Volume 17, No. 2, Oktober

meninggalkan tempat tugasnya pada suatu malam hari ketika turun hujan dengan sangat lebat disertai hembusan angin yang merobohkan pohon-pohon di sekitarnya dan disertai pula dengan kilat yang menyebar-nyebar, tetap berada di posnya dan untuk mencegah dirinya basah dan kedinginan ia memasuki gardu penjagaan kecil yang berada disitu dan menyelimuti dirinya dengan sarung yang memang ia pakai. Karena tidak ada teman berbicara dan mungkin pula karena kehangatan di dalam keadaan yang menjenukan itu ia telah tertidur tanpa menyadari bahwa kereta api akan lewat, dan menjadi kewajibannya untuk menutup pintu jalan kereta api yang ia jaga itu tepat pada waktunya. Kemudian ternyata bahwa pada waktu kereta api yang melintasi jalan raya itu lewat, ia tidak menutup pintu jalan kerata api sehingga terjadilah suatu kecelakaan yakni sebuah bus yang kebetulan lewat telah tertabrak oleh kereta api tersebut dan menyebabkan matinya semua penumpang yang terdapat di dalamnya.

Di dalam peristiwa tersebut tentunya sukar bagi kita untuk mengatakan bahwa penjaga pintu jalan kereta apai itu "tidak mempunyai kehatihatian" ataupun "kurang mempunyai perhatian terhadap kemungkinan
Ernest Sengi Konsep Culpa Dalam Perkara Pidana...

timbulnya suatu kecelakaan". Apakah dengan demikian ia menjadi tidak dapat dituntut karena matinya demikian banyak orang itu?

Tentunya saja ia dapat dituntut, oleh karena justru karena kesalahannyalah kecelakaan itu dapat terjadi dan karena kesalahan ia pula telah menyebabkan matinya banyak orang.

Perkataan "karena salahnya" disini mempunyai makna, bahwa kecelakaan yang telah menyebabkan matinya demikian banyak orang itu tidak ia kehendaki, atau dengan perkataan lain ia tidak mempunyai suatu opzet terhadap timbulnya akibat tersebut atau dengan perkataan lain lagi, pada orang tersebut hanyalah terhadap suatu culpa.

Cupla itu oleh ilmu pengetahuan dan yurisprudensi memang telah ditafsirkan sebagai "een tekort aan voorzienigheid" atau "een tekort aan voorzichtigheid" ataupun yang dalam doktrin juga sering disebut sebagai "een manco aan coorzienigheid" atau "een manco aan voorzichtigheid" yang berarti "suatu kekurangan untuk melihat jauh ke depan tentang kemungkinan timbulnya akibat-akibat" atau "suatu kekurangan akan sikap berhati-hati”, dan yang untuk membedakannya sering kali dalam doktrin dipergunakan perkataan- 
perkataan "onbewuste schuld" dan "bewuste schuld".

Sejalan dengan hal tersebut, Lamintang ${ }^{17}$ menyebut bahwa seseorang dapat dikatakan mempunyai "onbewuste schuld" dimana orang tersebut sama sekali tidak membayangkan kemungkinan akan timbul suatu akibat atau lain - lain keadaan yang menyertai tindakannya, walaupun sebenarnya ia " dapat " atau “ harus " berbuat demikian. Dari pendapat Lamintang tersebut, menurut Penulis harusnya konsep kealpaan dalam pertimbangan hakim pada konsep onbewuste schuld tersebut, karena fakta di persidangan bahwa terdakwa sendiri telah memberitahukan kepada setiap orang baik anak-anak, remaja, maupun orang dewasa bahkan terhadap korban sendiri sempat terdakwa sampaikan agar jangan mendekat pada kerambah ikan milik terdakwa sebab sudah dipasang aliran listrik. Itu berarti terdakwa sebenarnya sudah hati-hati dan telah memberikan perhatian terhadap apa yang diperbuatnya, hanya saja tidak membayangkan kemungkinan timbulnya akibat. Atas dasar itu, Penulis berbeda pendapat terkait konsep kealpaan (culpa) dengan majelis hakim dalam putusannya walaupun sebetulnya Penulis juga setuju terdakwa dikenai Pasal 359 KUHP.

\section{Mengakibatkan orang mati}

Dalam hal ini mengakibatkan orang mati yaitu perbuatan seseorang yang baik sengaja maupun tidak disengaja menimbulkan akibat yang mengakibatkan mati. Dalam putusan No.18/Pid.B/2017/PN.Tob menyatakan dengan hasil visum et repertum no. Ver/049/1722/2016 tertanggal 23 november 2016 yang dibuat dan ditandatangani oleh dr. William, dokter pemeriksa di RSUD Tobelo dengan hasil pemeriksaan yaitu :

- Kaku mayat seluruh badan sukar dilawan

- Lebam mayat pada punggung atas dan bawah yang tidak hilang pada penekanan

- Hidung keluar cairan darah warna merah dari lubang hidung kanan, kiri

- Kuku pada kaki dan tangan tampak kebiruan

- Luka

- Pada telapak tangan kanan, tampak luka kehitaman pada jari pertama, kedua, tiga, keempat, dan lima dan seterusnya

\footnotetext{
${ }^{17}$ Ibid., hal. 338.
} 
Kesimpulannya : luka akibat trauma listrik. Dalam perkara ini yang dihadirkan untuk divisum adalah korban Mustahidin Samad maka keterangan tersebut adalah benar.

Dari hal uraian tersebut maka menurut penulis bahwa pendapat hakim mengenai tindak pidana kealpaan yang dilakukan terdakwa Imsal Ilahi Baksi, sebenarnya banyak hal yang harus dilihat diantaranya unsur kealpaan itu sendiri. Dimana hakim mengartikan kealpaan sebagai suatu perbuatan yang kurang hati - hati atau kurang perhatian, namun menurut penulis bahwa kurang hati-hati dalam kasus tersebut sebenarnya perlu untuk dikaji kembali. Sebab, yang dimaksud kurang hati-hati dalam teori kealpaan harus juga disertai dengan membayangkan akan suatu akibat. Dalam kasus yang terjadi, terdakwa sebenarnya sudah hati-hati dan telah memberikan perhatian, dimana dapat dilihat dari pernyataan terdakwa mengenai pemberitahuannya kepada orang-orang disekitar bahkan kepada korban sendiri bahwa terdakwa telah memasang aliran listrik pada keramba dengan maksud untuk mencegah terjadinya pencurian ikan. Dengan demikian menurut Penulis bahwa terdakwa dengan pemberitahuan ini sudah sangat hati-hati dan tidak mengehendaki untuk mengakibatkan matinya orang.

\section{PENUTUP}

\section{A. Kesimpulan}

Kesimpulan yang dapat ditarik dari uraian pembahasan tersebut yakni bahwa perbuatan terdakwa yang didakwa melanggar Pasal 359 KUHP menurut Penulis sudah tepat di kenakan majelis hakim Pengadilan Negeri Tobelo terhadap terdakwa; namun dalam mempertimbangkan unsur kealpaan (culpa) oleh majelis hakim dalam putusannya masih sangat tidak relevan khusunya terkait unsur "kealpaan". Sebab menurut majelis hakim kealpaan dalam kasus ini hanya dilihat dari perbuatan terdakwa yang "kurang hati-hati atau kurang perhatian”, sementara itu konsep kealpaan dalam teori hukum pidana tidak dipahami sekedar hanya kealpaan dalam arti "kurang hati-hati atau kurang perhatian" melainkan kealpaan dalam arti kekurangan untuk melihat jauh ke depan tentang kemungkinan timbulnya suatu akibat. Karena faktanya, dalam perkara ini terdakwa sudah hati-hati dan telah memberikan perhatian dengan cara memberitahukan perbuatannya (memasang aliran listrik), namun hanya tidak membayangkan kemungkinan 
Ernest Sengi

timbulnya akibat. Hal inilah yang dalam teori dikenal dengan perkataan onbewuste schuld yang menurut Penulis harusnya lebih tepat digunakan dalam konsep kealpaan pada pertimbangan hukum perkara ini.

\section{B. Saran}

Berdasarkan kesimpulan tersebut, maka ke depan diharapkan hakim dalam mempertimbangkan unsur kealpaan (culpa) dalam putusan harus lebih detail, teliti dan tepat dimana tidak hanya sekedar berpatokan pada konsep sederhana dari kealpaan (culpa). Karena, perbuatan yang dikategorikan sebagai kealpaan "dari aspek hukum" tidak sama dengan kealpaan yang pahami secara umum yang merupakan peristiwa biasa.

\section{DAFTAR PUSTAKA}

\section{A. Buku:}

Harahap, M. Yahya. Pembahasan Permasalahan dan Penerapan KUHAP, Penyidikan dan Penuntutan. Jakarta: Sinar Grafika, 2008.

Lamintang, P.A.F. Dasar-Dasar Hukum Pidana Indonesia. Bandung: Citra Aditya Bakti, 1997.

Lamintang P.A.F. dan Theo Lamintang, Delik-Delik Khusus: Kejahatan Terhadap Nyawa, Tubuh dan Kesehatan. Jakarta: Sinar Grafika, 2010.
Marzuki, Peter Mahmud. Penelitian Hukum, edisi revisi. Jakarta: Kencana Prenada Media Grup, 2013.

Moeljatno. Asas-Asas Hukum Pidana. Jakarta: Rineka Cipta, 2008.

Simons. Leerboek van het Nederlandse Strafrecht, P. Noordhoff N.V., Groningen - Batavia, 1937.

Soekanto, Soerjono dan Sri Mamudji. Penelitian Hukum Normatif, Suatu Tinjauan Singkat. Jakarta: Raja Grafindo Persada, 2012.

\section{B. Jurnal:}

Candra, Septa. "Pembaharuan Hukum Pidana; Konsep Pertanggungjawaban Pidana Dalam Hukum Pidana Nasional Yang Akan Datang." Jurnal Cita Hukum. Volume 1, Nomor 1 (Juni 2013): 39 - 56.

Kalia, Hariati. "Pembuktian tindak pidana dengan terang-terangan dan tenaga bersama menggunakan kekerasan terhadap orang yang mengakibatkan luka-luka (studi putusan nomor: 256/pid.b/2010/pn.dgl)".

Jurnal Ilmu Hukum Legal Opinion. Edisi 4, Volume 1, (Tahun 2013): $1-8$.

Paidun, Hendri. "Tinjauan Terhadap Tindak Pidana Kealpaan Yang Menyebabkan Matinya Orang Yang Dilakukan Oleh Pengemudi Kendaraan 
Volume 17, No. 2, Oktober

Bermotor." Jurnal Lex Crimen.

Volume II, Nomor 7

(November 2013): 119 - 127.

Widyantara, I Made Minggu. "Kesengajaan Dan Kealpaan (Suatu Tinjauan Dari Sudut Perbandingan Hukum Pidana Indonesia Dengan Hukum Pidana Asing) Jurnal Kertha Wicaksana. Volume 21, Nomor 1 (Januari 2017): 1 - 4.

\section{C.Peraturan dan Putusan:}

Rizki, Gerry M. KUHP dan KUHAP.

Jakarta: Permata Press, 2008.

Putusan Pengadilan Negeri Tobelo Nomor 18/Pid.B/2017/PN.TOB., Tahun 2017. 